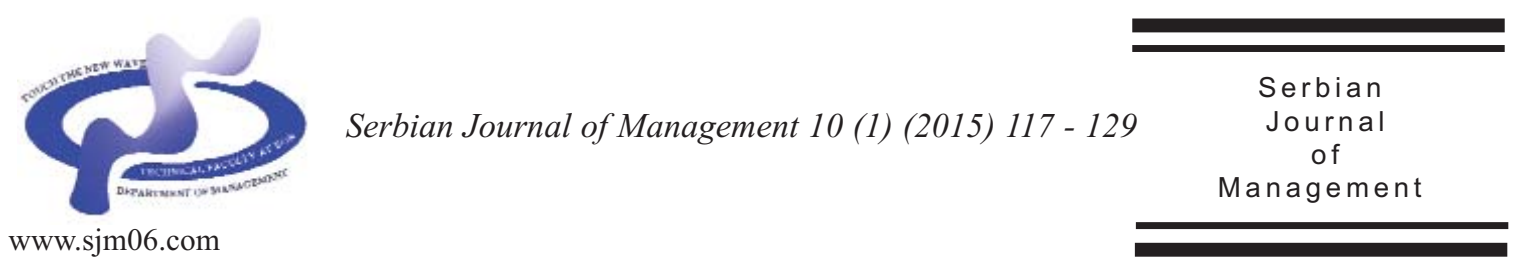

\title{
CITIZEN SATISFACTION SURVEY AS A TOOL OF CITIZEN RELATIONSHIP MANAGEMENT OF LOCAL GOVERNMENT IN SLOVAKIA
}

\author{
Milan Fil'a ${ }^{a^{*}}$, Loreta Schwarczováa and Ladislav Mura ${ }^{b}$ \\ $a_{\text {Slovak University of Agriculture in Nitra, Faculty of European Studies and Regional }}$ \\ Development, Department of European Policies, \\ Tr. A. Hlinku 2, 94976 Nitra,Slovak Republic \\ $b_{\text {Department of Public Administration }}$ \\ University of Ss. Cyril and Methodius in Trnava, Faculty of Social Sciences, \\ Nám. J. Herdu 2, 91701 Trnava, Slovak Republic
}

(Received 16 November 2014; accepted 3 March 2015)

\begin{abstract}
Citizen Relationship Management (hereinafter referred to as CiRM) becomes increasingly important in the countries of so called post-communist Europe nowadays. The communication process in the citizen -municipality relationship is at present no longer about one-way informing of the citizens about orders, prohibitions or obligations. People want to be informed and to be at the heart of the process. At the same time, considering the democratic development of society and modern technical means, they also feel the need both to actively participate in the public life through expressing their opinions, comments or suggestions, and to influence the development of the environment in which they live. Not only enterprises but also the state and public administrations and regional and local self-governments inevitably have to adapt to it. Based on the research carried out in the cities of the Slovac Republic (SR), in which currently approximately $55 \%$ of all citizens of Slovakia live, the presented scientific paper evaluates the current state, level and the importance of the conduct of local citizen satisfaction surveys in relation to local governments as a tool of the CiRM managed by the municipal authorities or by any persons or institutions authorized by them. Thispaper also points out several deficiencies it entails particularly in the area of publication of identified findings by the cities of the SR.
\end{abstract}

Keywords: CiRM, communication, citizens, municipalities, regions

\section{INTRODUCTION}

Cities and municipalities provide their citizens with a certain range of public services that ensure the level of the overall comfort of life in the local environment in which they live. Their intensity is higher especially in the cities, where there is a higher concentration of the population. The higher the concentration of the services and

\footnotetext{
*Corresponding author: milan.fila@gmail.com

DOI:10.5937/sjm10-7147
} 
the population, the more inevitable is the need for ensuring both appropriate tools of communication with citizens and the acquisition of the feedback on the quality of the services provided.The significance of the pro-active communication at the municipality level is highlighted also by Kubica (2008), according to whom such a communication brings further opportunities enabling more effective informative or public relation (PR) activities (Novotný, 2013). Among pro-active methods of municipality communication we can identify not only creation of effective communication channels but also technical background, available infrastructure which may enhance or - slow the information flow. The necessity is the elimination of communication barriers with special attention to those which are not recognized by the public. According to various international declarations, as well as the findings of previous research, the question of transparency of public bodies with respect to sustainability is a subject of great current interest in the relationship between administrations and citizens as demonstrated by Alcaraz-Qiles et al. (2014).

Vidová et al. (2007) inclines to agree with the idea as well and claims that an active marketing communication is necessary, because from the perspective of the new approaches to the governance and the management of the municipalities, in terms of which the local authority is considered to be a provider of the public services and one of its tasks comprises the fulfilment of the needs of citizens as well.

As customers experience an increase in the involvement and the provision of and the access to the services in the private sector, they now demand the same from the public sector. Citizens today expect the government service to be as good as or better than that received by private providers. Meanwhile, governmentsall over the world are pressured by population growth and demographic change, technological and knowledge explosion and the citizens' increasing expectations combined with their tax reluctance. As a result, the governments begin to adopt CiRM practices in order to respond to the demands of citizens (Coleman, 2004). As Shan et al. (2015) explain a more inclusive 2-way communication model with interactive processes suggests that communication practitioners need to engage with the public to discover their level of knowledge, attitudes, behavior patterns, and information needs. To this end communication channels that facilitate listening, feedback, participation, and dialogue are considered a key resource not only to ensure that the public's voice is being heard but also to provide substantive input that will improve the organization's information services and communication outcomes.

Foret (2011) states that a precondition for the development of any territory is the cooperation of public administration with both citizens and entrepreneurs. Citizen Relationship Management (CiRM) is a division of customer relationship management that focuses specifically on how governmental bodies act towards their constituents (Schellong \& Langenberg, 2007).

The CiRM framework is described by Figure 1.

Citizen Relationship Management (CiRM) can be defined as a strategy enabled by technology with a broad citizen focus, to maintain and optimize the relationship and to encourage the participation (Anttiroiko \& Mälkiä, 2007).

Kannabiran et al. (2004) write that CiRM 


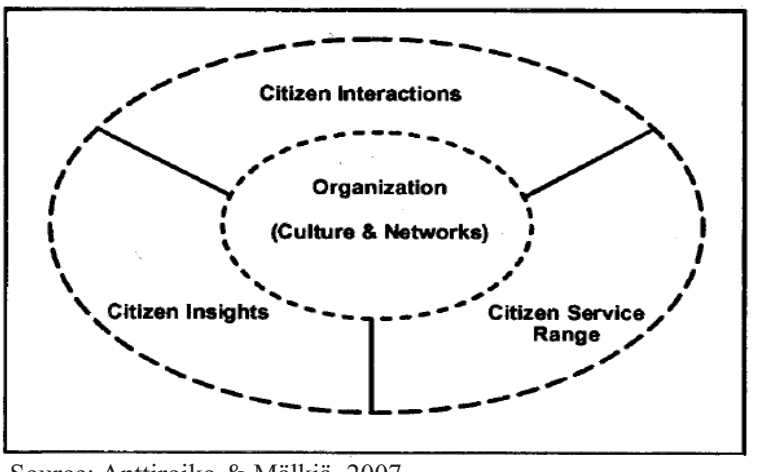

Source: Anttiroiko \& Mälkiä, 2007

Figure 1. The CiRM framework

is about becoming "citizen-centric". It is a strategic opportunity to harness processes and technology to:

1. Provide service excellence by increasing the efficiency of service and information delivery to citizens.

2. Provide (where legally possible) a government-wide view of each citizen.

3. Build and strengthen the links and co-operation between government, its citizens, and stakeholders.

4. Realize operational and financial efficiencies.

5. Assist in community building and outreach.

6. Build and environment, which encourages innovation (Novotný, 2010).

Citizen Relationship Management's goal is to provide citizens with the highest quality services at the lowest cost to taxpayers by focusing the government's resources in the best way for each citizen. CiRM is about providing timely, consistent and responsive access to government information and services by whatever channel citizens prefer (Burt et al., 2005). According to Hudáková (2006), communication with the public comprises objective informing of citizens, effective communication with the mass media, handling potential criticism expressed by the public and the successful participation in all of the external communication activities in general.

As up to $55 \%$ of the citizens of the SR currently live in 136 Slovak cities, the subject of the research carried out is the communication on the level of citizen -municipality aimed at the level and the importance of the citizen satisfaction survey as a tool contributing to the development of the Slovak cities and life in them and the quality of the public services provided.

\section{MATERIAL AND METHODS}

When elaborating this scientific paper, we used theoretical knowledge and information obtained from available domestic as well as foreign literary sources consisting primarily of secondary information sources.

The primary information, which was used when writing the paper, was represented by the questionnaire-based survey which we conducted at the city level and through which we approached all 136 cities of the SR. This number stood for the basic file we researched. The survey focused on studying the satisfaction and the opinions of citizens related both to the level of information provided by the cities and to the forms of its provision and publication. The questions we set up were answered mainly by the employees responsible for ensuring communication of the cities with the public (depending on the organizational structure of the city of the SR they were the heads of and the employees of either communication departments or public relations departments of relevant cities).

Our selected file represented 124 cities that returned questionnaire replies and hence provided data for further processing and research. Of the total number of the cities 
approached, i.e. the basic file, up to $91.18 \%$ formed the selected file.

To verify the representativeness of the selected file of the cities, we used the Pearson's chi-squared goodness of fit statistical test, which can be expressed in the following way:

$$
X^{2}=\sum_{i=1}^{r} \frac{\left(n_{i}-e_{i}\right)^{2}}{e_{i}}
$$

This statistic asymptotically approaches a $\mathrm{X}^{2}$ division with the $\mathrm{r}-1$ degrees of freedom. It is based on the frequency table and tests the null statistical hypothesis stating that the numbers in the individual categories are equal to the expected (theoretical) numbers (Rimarčík, 2007).

On the basis of the calculation of the tested characteristic (TCH) and its subsequent comparison with the critical value $(\mathrm{CV})$, we may confirm the established hypothesis $\mathrm{H} 0$, and thus that the selected file of the researched cities is representative.

When examining the questionnaire replies, we focused also on the identification and the verification of the existing preferences in the answers concentrating on the perception of the importance and the evaluation of the transparency related to the amendment to the Act on free access to information. In terms of the verification, we used the Kolmogorov-Smirnov test, which is a nonparametric test belonging among the

Table 1. Testing of the representativeness of the selected file by means of Chi-square goodness of fit test

\begin{tabular}{|c|c|}
\hline alpha & 0.05 \\
\hline $\mathrm{TCH}$ & 0.3604351 \\
\hline $\mathrm{CV}$ & 14.06714045 \\
\hline \multicolumn{2}{|c|}{$\mathbf{T C H}<\mathbf{C V}$} \\
\hline
\end{tabular}

Source: own research, 2014 tests of equal distribution. Its use is suitable when testing the ordinal data in 1 selected file, while it is desirable to compare the preferences found out with theoretical or hypothetical preferences (ordering). It is designed to test the null hypothesis $\mathrm{H}_{0}: \mathrm{F}(\mathrm{x})=\mathrm{G}(\mathrm{x})$ for all $\mathrm{x} \in \mathrm{R}$ against the alternative hypothesis $\mathrm{H}_{1}: \mathrm{F}(\mathrm{x}) \neq \mathrm{G}(\mathrm{x})$ at least for one $x$, while $F$ and $G$ are distribution functions of two independent samples. The tested characteristic D is calculated on the basis of the following relationship:

$\mathrm{D}=\max \left|\mathrm{E}_{\mathrm{i}}-\mathrm{T}_{\mathrm{i}}\right|$

And it is compared with the tabulated V value, the calculation of which is dependent on the level of significance chosen and is given by the following functional relationship:

$\mathrm{H}=\frac{1,36}{\sqrt{\mathrm{n}}}, \infty=0,05$

In addition to the above methods, to examine the issue in a complex way, we also used the methods of analysis, synthesis and comparison of both primary and secondary data obtained.

On the basis of the identified results, we formulated conclusions related to the level and the importance of the survey on the citizen satisfaction in terms of the provision of information and the communication with the public in the conditions of the Slovak Republic.

\section{RESULTS AND DISCUSSION}

Caywood (2003) talks about the precondition of two-way communication so 
called free flow of information, while the information goes out and then returns in the form of a feedback between state administration authorities and the citizens themselves.

From our perspective, this model can be transferred on the level of municipalities ensuring local provision of the public services. The active use of the CiRM by means of an open and regular communication of cities and municipalities with their citizens is an important feature of democracy and the maturity of today's modern society. In order to ensure the twoway flow of information and the feedback acquisition, it is necessary to survey the level of the satisfaction of the citizens through various communication channels.

\subsection{Degree of Surveying of Satisfaction of the Citizens of the Slovak Cities}

Surveying of the satisfaction of the citizens by themunicipalities is really important in terms of their further development and the improvement of the provision of information to either public services or the employees themselves, the objective evaluation of whom may reflect the findings of such a survey, which is also confirmed by Malik (2010) arguing that when people feel fairly or advantageously treated they are more likely to be motivated; when they feel unfairly treated they are highly prone to feelings of disaffection and demotivation. The way that people measure this sense of fairness is at the heart of Equity Theory.

At the same time, such a survey stands for a certain expression of interest in the very citizen or citizens, who are more actively involved in public affairs in this way.

In spite of the abovementioned facts,

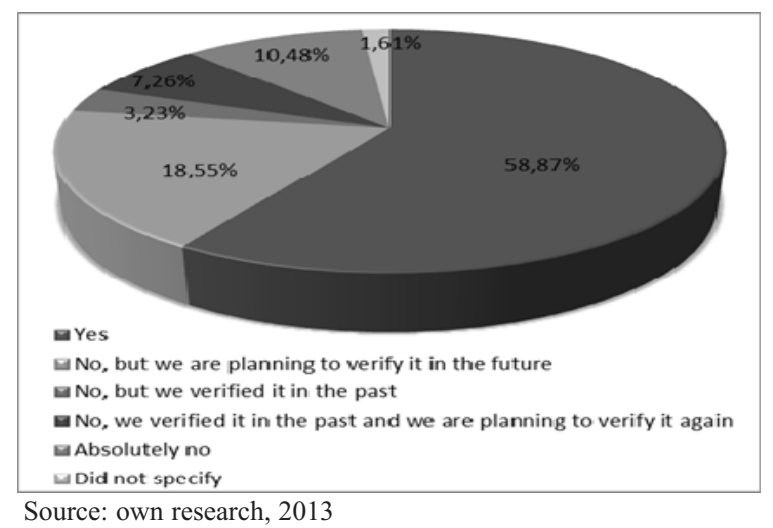

Figure 2. Surveying the level of citizens' satisfaction in terms of the provision of information by the Slovak cities

there is still considerable work to be done in terms of the degree up to which satisfaction of citizens is surveyed by the local authorities. The questionnaire-based survey that we carried out leads to a conclusion that only less than $60 \%$ of the cities survey the citizens' satisfaction in terms of the information they are provided. The rest of the cities representing more than $40 \%$ do not conduct such surveys at all, while a certain part of them used to conduct such surveys in the past, but refrained from doing so. Over $18 \%$ of the cities plan to introduce the surveying as a new form of communication and acquisition of feedback from their citizens. See Figure 2 in more detail.

If we look at the surveying of the level of citizens' satisfaction from the regional perspective of the NUTS III level, i.e. the perspective of the Slovak regions, we may come to some interesting conclusions. The greatest interest in conducting the surveys is expressed by the cities of Žilina, Banská Bystrica and Nitra Regions. Paradoxically, the lowest number of the cities conducting the local surveys is in the Bratislava Region. The rest of the regions oscillate just below the national average. The results, however, 


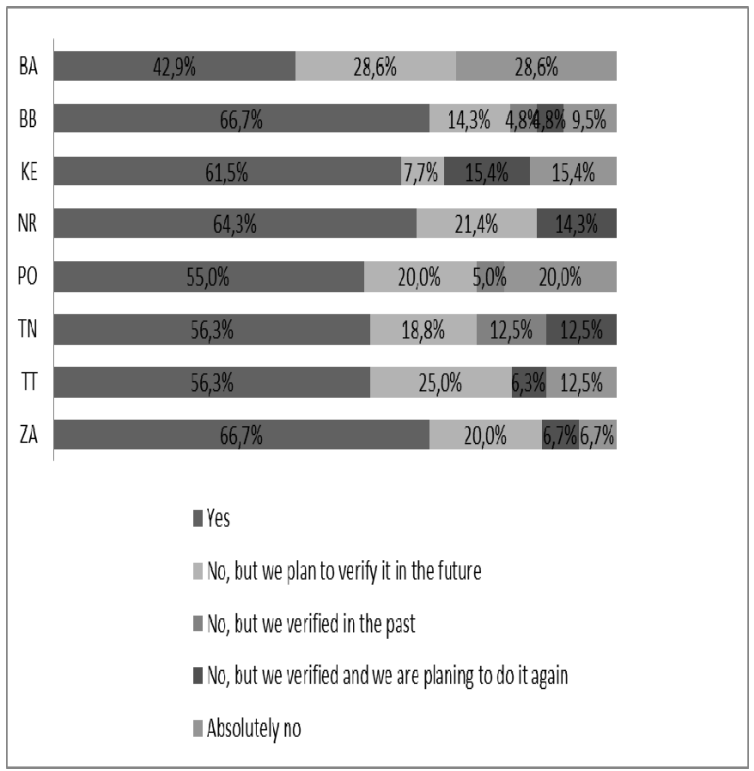

Source: own research, 2013

Figure 3. Surveying the level of citizens' satisfaction in terms of the information they are provided by the cities of the $S R$ in individual regions

do not change even after including the cities not conducting the surveys among their citizens but planning to do so in the future. A more detailed overview is provided by the previous Figure 3.

In the cities conducting the citizen satisfaction surveys, we subsequently examined whether such surveys are conducted regularly and systematically or whether it is rather a random activity done on specific occasions. Based on the replies obtained, we can state that approximately $1 / 3$ of the cities, which survey the satisfaction of their citizens in terms of the information provided to them, declared it as being regular and systematic. By contrast, more than $60 \%$ of the cities do such activities in an irregular, random and therefore unsystematic manner (see Figure 4 in more detail).

On the basis of the abovementioned findings, we may also state that an

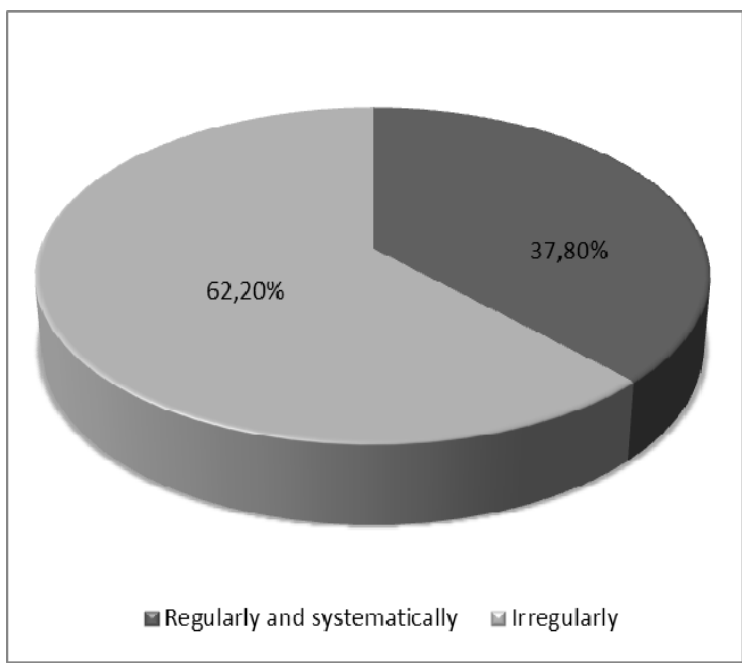

Source: own research, 2013

Figure 4. Regularity of surveying of the level of citizens'satisfaction in terms of the information provided by the cities of the $S R$

alarmingly low number, i.e. approximately $22 \%$ of all the cities of the SR, conductsthe local surveys on the citizens' satisfaction in terms of the information provided to them regularly and systematically in order, for instance, to improve the quality of the public services, transparency and the active involvement of the citizens in public affairs. In terms of the overall evaluation in the context of the present day, marked by provision of information and modern technologies, the number is very low.

\subsection{Length of the Period of Surveying} of Satisfaction of the Citizens of the Slovak Cities and Publication of Results

In addition to observing whether such surveys are of the regular and systematic nature or not, the overall picture concerning the importance and benefits of the citizensatisfaction surveys also comprises the aspect of the length of the period of the very surveying and the publication of the identified results, which can be subsequently 


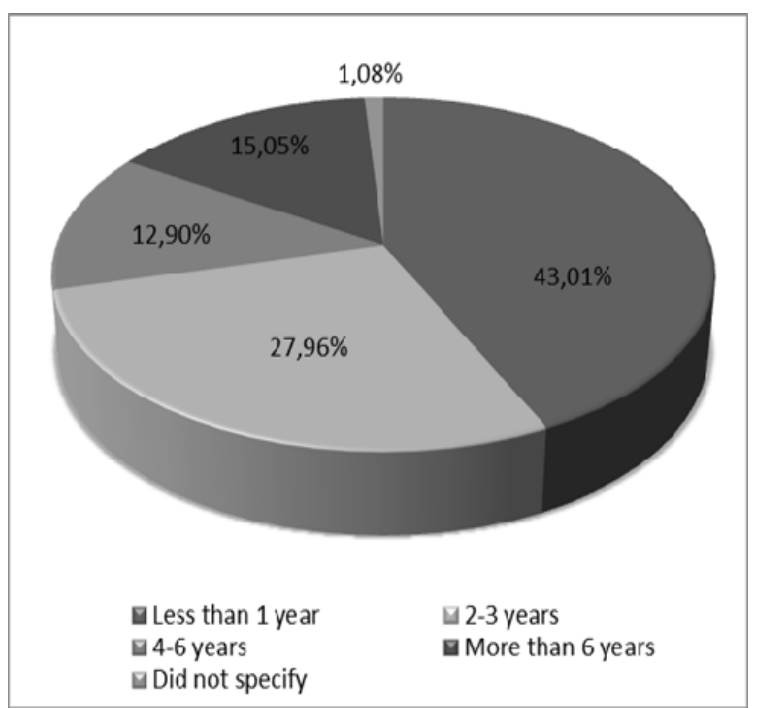

Source: own research, 2013

Figure 5. Length of the period of surveying of the level of citizens' satisfaction in the cities of the SR conducting local surveys

provided to citizenswho represent the respondents of the surveys.

One of the key terms, which are currently used in relation to the performance of public administration and public authority, is transparency. It is related to the availability of information, including their publication through traditional and modern technical means. The obligation to make the information public and available is legislatively supported by the Act No. $211 / 2000$ Coll. on free access to information and amending and supplementing certain laws, as amended. The Act imposes an obligation on the obliged person to provide access to information, while the obliged persons are, inter alia, understood as representing state agencies, municipalities, as well as legal entities and natural persons that have been given the power by the law to make decisions on the rights and duties of the natural persons or legal entities in the area of public administration, and that obligation applies mainly within the scope of their decision-making power. Therefore, for the purposes of this Act, obliged persons are, inter alia, cities and municipalities, their mayors, city or municipal councils; local, city, or municipal authorities, etc.

In spite of the abovementioned Act, only approximately $40 \%$ of Slovak cities publish the results of the local surveys on their citizens' satisfaction on their own initiative. By contrast, approximately the same percentage of cities does not publish the results and leaves them only on the level of the internal material of their city authorities. And more than $20 \%$ of the cities completely refused to answer that question, from which we can deduce that even in this case, the publication of information is more than questionable. A more detailed overview is provided by Figure 6 .

If we look at the issue of the publication of the survey results in terms of individual regions, we come to some very interesting conclusions. The lowest level of publication is identified in the cities of Bratislava and

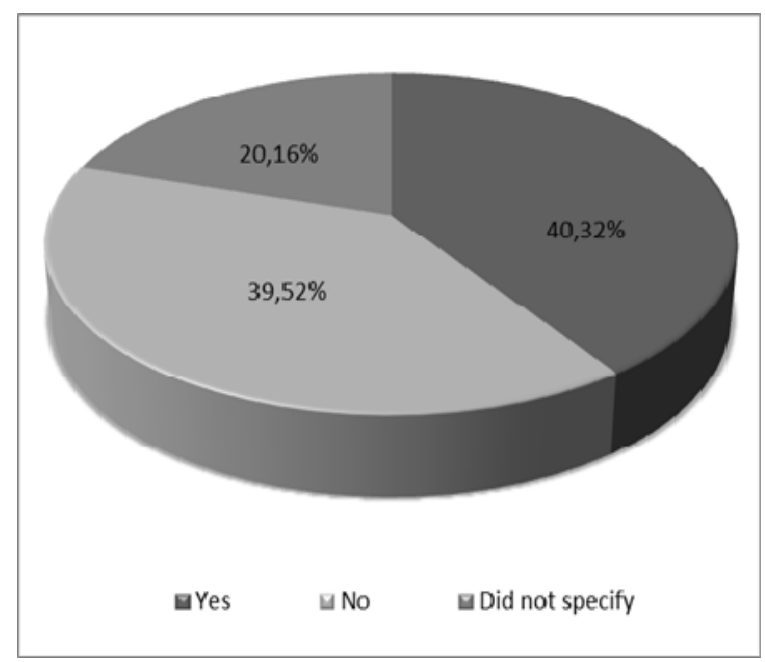

Source: own research, 2013

Figure 6. Publication of the results of the survey on the satisfaction in the cities of the SR 
Košice Self-Governing Regions, i.e. in the regions, in which the 2 largest cities of the SR are situated and in which relatively substantial amount of Slovakia's economic activity is concentrated. But we can only speculate on the reasons for it. On the other hand, the highest level of publication and thus openness related to presenting the citizens with the results of the local surveys were achieved in the cities of Žilina, Banská Bystrica and Nitra Self-Governing Regions. Those are also the regions with the highest proportion of the cities conducting the local surveys. The reasons can be searched for, for example, in the effort made by the representatives of the municipalities to be truly open and transparent and also in the effort to find out the real opinions, needs and suggestions of the population. Those regions prove it with projects such as Transparent Town (Martin, Šal'a), Open Region (Žilina Self-Governing Region) or the forum aimed at finding out citizens' suggestions and opinions social networks (Nitra). See Figure 7 in more detail.

Important national negative preferences related to the publication of the results of local citizens' satisfaction surveys conducted by the SR cities are also demonstrated by the results of Kolmogorov-Smirnov test presented in the following Table 2. Based on the comparison of the tested characteristic and the tabulated value, the calculation of which is described in the section named Material and Methods, we found out that we could reject the null hypothesis $\mathrm{H} 0$ and accept the alternative hypothesis $\mathrm{H} 1$ confirming our assumption that there are statistically significant differences in the preferences of the SR cities.

Although the Act on free access to information does not explicitly order the municipalities to publish the surveys they

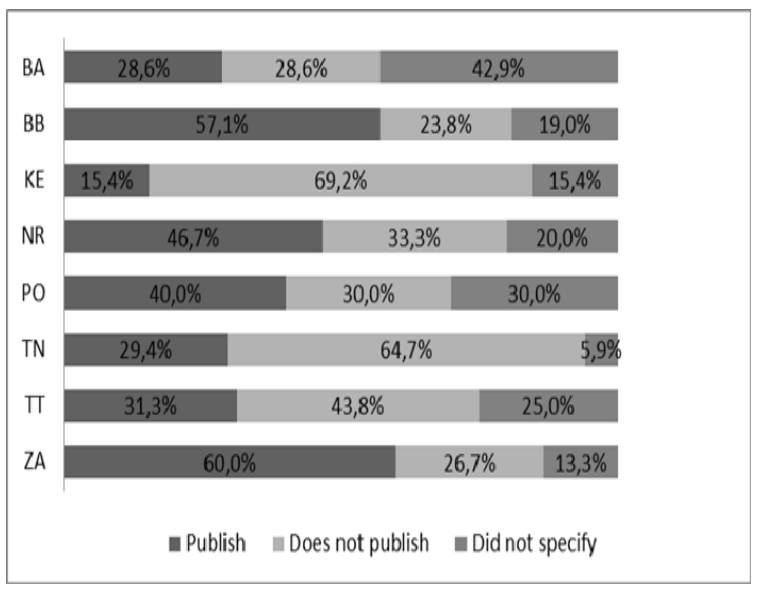

Source: own research, 2013

Figure 7. Publication of the results of the satisfaction surveys in the SR cities based on the regional distribution

conduct, publication of specific documents is defined particularly with regard to the management of public means and property, and pursuant to the Act it is possible to ask for them. That is one of the reasons why the publication of such data makes sense, of course, in aggregated form of the overall results with aim of pointing out the identified overall condition in the present case of the local citizens' satisfaction surveys. At the same time, such publication of results gives the citizens a sense of real utilization of information they are asked about and

Table 2. Kolmogorov-Smirnov test (publication of the results of the satisfaction surveys)

\begin{tabular}{|c|c|c|}
\hline $\mathrm{n}$ & & 124 \\
\hline alpha & & 0.05 \\
\hline \multicolumn{3}{|c|}{ Values } \\
\hline D calc & 0.40 & $\begin{array}{c}\text { max. value } \\
\text { from abs (Fi-Gi) }\end{array}$ \\
\hline D tab & \multicolumn{2}{|r|}{0.12213} \\
\hline \multicolumn{3}{|c|}{$D$ calc $>$ D tab } \\
\hline
\end{tabular}

Source: own research, 2013 


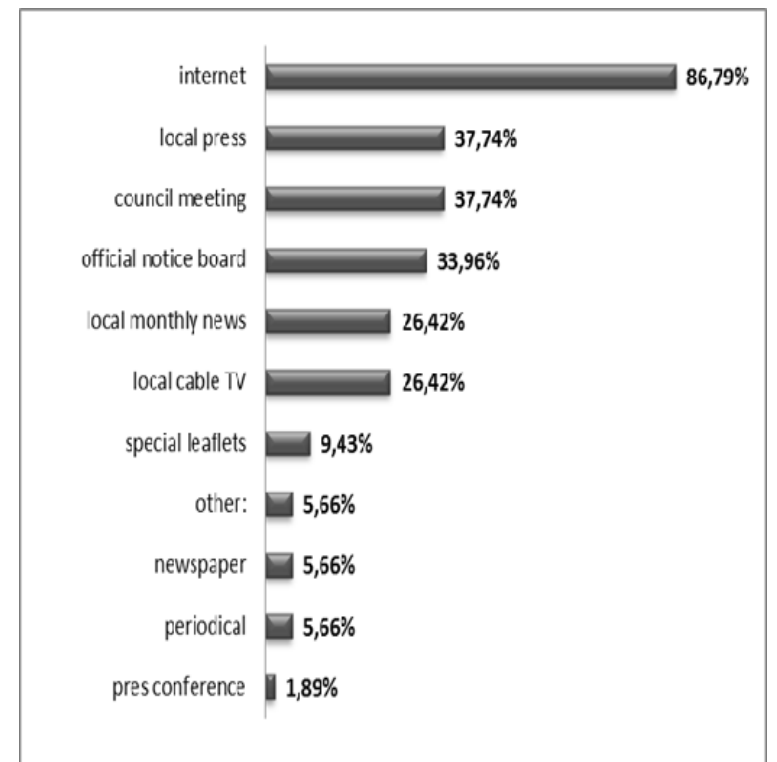

Source: own research, 2013

Figure 8. Methods of publication of the results of the satisfaction surveys in the SR cities

indicates the openness of local authorities towards potential criticism or identified dissatisfaction.

Nowadays, the largest part of the cities publishing the results of the surveys uses modern technological means and publishes the results on the Internet particularly via their own websites. This part comprises more than $86 \%$ of the cases. It is followed by the means of local press and city council sessions in $37.74 \%$ of the cases and bulletin board in $33.96 \%$ of the cases. Local monthly periodicals issued by individual municipalities and local or regional televisions (approximately 26\% of the cases) are also important. Press, conferences, blogs and so on represent only a negligible number of cases (see Figure 8).

Today's modern times require modern approaches to communication with citizens as well. As for the cities publishing the results of the local surveys, that is also the reason why we focused on evaluation of the level of the use of the Internet for those purposes and we did so at the level of individual Slovak regions.

As we can see in Figure 9, the highest $100 \%$ rate of publication of the results on the Internet is utilized by the cities of Bratislava, Trenčín and Prešov Regions. It is slightly worse in the cities of Banská Bystrica and Trnava Regions. The worst results were found out in the cities of Košice and Žilina Self-Governing Regions, where the rate of the use of the Internet for publication of the results of the local surveys is only 50 or 70 per cent. We can search for the reasons, for instance, in the fact that the use of the Internet is still not a tradition in the case of the given regions and their local authorities, because many parts of north or east of Slovakia are not yet covered by high-speed Internet with the exception of the regional capitals or the largest cities. There is still a tradition of informing citizens through the tools such as local radio, local newspaper or local council sessions especially in the smaller cities.

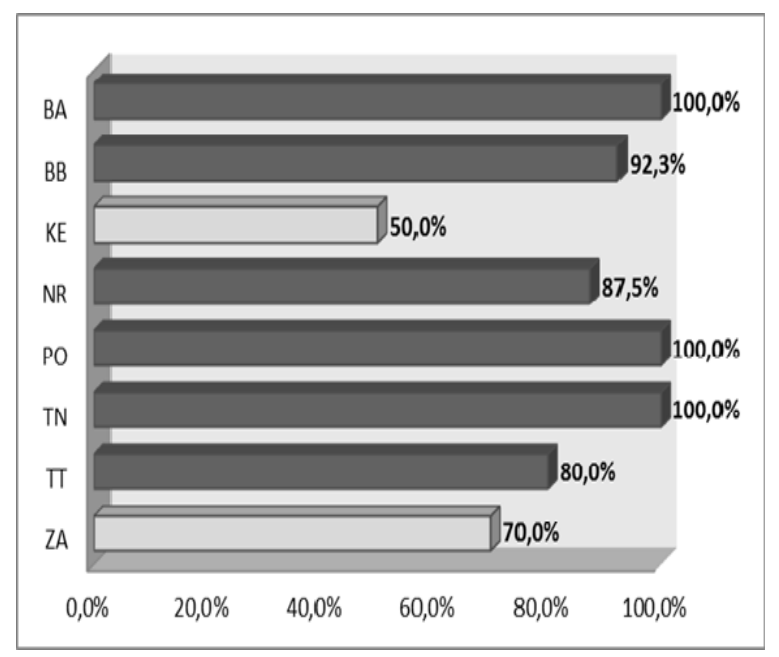

Source: own research, 2013

Figure 9. Publication of the results of the satisfaction surveys in the cities of the SR via the Internet based on the regional distribution 
3.3. Reasons and Benefits of the Surveys on Satisfaction of the Citizens of the Slovak Cities

Every survey conducted thanks to the municipalities' public resources should focus on a specific purpose and represent a certain benefit to the given municipality, because otherwise we could talk about an ineffective use of public resources.

The results of our research suggest that the main reason for the conduct of the local citizen satisfaction surveys is the fact that the opinions and the needs of the citizens constantly change and the results of the surveys help the local authorities to make the right decisions on the provision of services, while this statement is agreed upon by more than the half of the respondents from the government of the SR cities. Another important reason is the effort to create another method of communication between citizens and the city offices, which shall ensure the exchange of information and the acquisition of the feedback. In almost 1/5 of the cases, the results of the local surveys serve as a helping basis for a possible

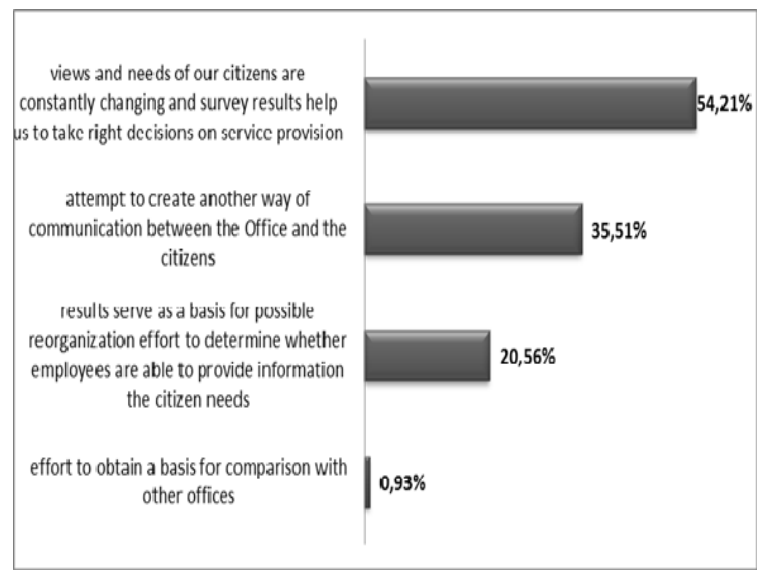

Source: own research, 2013

Figure 10. Reasons for the surveys on satisfaction of the citizens of the Slovak cities reorganization or for an effort to find out whether workers are able to provide information that citizens need in an adequate amount, quality and time (for more detail, see Figure 10 above).

From the perspective of another strategic development of the cities, their representatives find the greatest benefit of the local citizen satisfaction surveys to be mainly the acquisition of another (additional) information necessary for further development in all areas that are under the influenced of the local authorities $(52.34 \%$ of the cases).

As further suggested by the results in Figure 11, it, is very important for the local governments to obtain information, thanks to which it is possible to establish the vision of further direction of the development of the cities (40.19\% of the cases). According to $25.23 \%$ of the cases, the most important benefit is considered to be the finding out of the opinions of local residents before the cities make any fundamental (strategic)

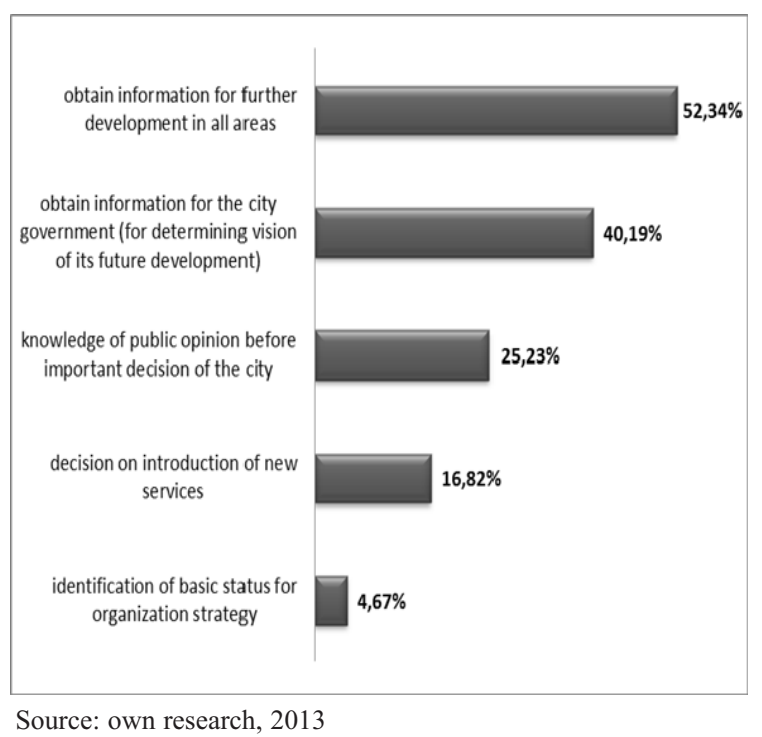

Figure 11. The greatest benefit of the citizen satisfaction surveysconducted by the SR cities from the perspective of their further strategic development 
decisions, which may significantly affect their further development. Only the minimum number of the SR cities finds the most important benefit to be the decisionmaking related to the introduction of new services or surveying the situation for a potential organizational strategy (organizational changes) on the level of authorities.

\section{CONCLUSION}

There is still considerable work to be done in relation to the local citizen satisfaction surveys conducted by the representatives of the Slovak municipalities, because only less than $60 \%$ of the cities conduct such surveys and just over a third of them does so regularly and systematically. Most of the cities have introduced the citizen satisfaction surveys just recently and thus the surveys and the active involvement of the local citizens in the management of public affairs in the Slovak cities is still not a sufficiently strong tradition. Only about a third of the cities conducting the surveys has been doing so for more than 4 years. Publication of the results of the surveys conducted was identified in less than one half of the cases. It is mainly the Internet and the web pages of the cities, local press, local council sessions, bulletin boards or local televisions which are used for the purposes of the publication of the results. It is possible to believe that several surveys of some cities remained only an internal material or have not been presented publicly, for example, because of identification of a negative picture of the situation. Even in spite of the Act on free access to information was adopted, most of the cities do not public such data automatically, because it is not explicitly required by the Act, however, manytimes, it can result in the disappearance of the effect the surveys have, because the citizens cannot see the results, which would evoke their active involvement in both public life and the development of their cities. Positive examples are provided, for instance, by the projects such as Transparent Town or Open Region, which are currently carried outby the cities of Martin and Šal'a andŽilina SelfGoverning Region, which also forms a positive relationship and open possibilities of control and co-operation with citizens (Rebeca, 2014).

However, in order for the most of the cities to reach such a system, it is necessary to think about the quality and the development of human resources in the local public administration. As stated by Mura (2012), the globalization makes organizations need people who can adapt in any economic, cultural, political, and technical environment. We must invest in human resources development in order to face changes successfully no matter how provocative they are.

Cities in the SR conducting the surveys do so mainly because their representatives had come to a conclusion that the opinions and the needs of their citizens constantly develop and change and hence the results of the surveys help to make the right decisions in the area of public administration. From the perspective of the strategic development of the cities, the information obtained is the most valuable for the further development in all areas, including the basis for the government of the city to be able to define the visions concerning the further directions both of the city and the local government properly. 


\title{
ИСТРАЖИВАЊЕ ЗАДОВОЉСТВА ГРАЪАНА КАО АЛАТ УПРАВЉАЊА ЈАВНИМ ОДНОСИМА ЛОКАЛНИХ ВЛАСТИ У СЛОВАЧКОЈ РЕПУБЛИЦИ
}

\author{
Milan Fil’a, Loreta Schwarczová, Ladislav Mura
}

\begin{abstract}
Извод
Управљање односима греађана (у даљем тексту означено као “CiRM") постаје изузетно значајно у земљама такозване пост-комунистичке Европе. Процес комуникације у односима грађанин - општина није више једносмерно информисање грађана о наређењима, забранама или обавезама. У данашње време људи желе да буду информисани како би били у средишту догађања. У исто време, имајући у виду демократски развој друштва и модерна техничка средства, такође осећају потребу како да активно партиципирају у јавном животу преко изражавања својег мишљења, коментара или сугестија, тако и да утичу на развој окружења у којем живе. На то се не требају навићи само компаније, већ и државна и јавна администрација, али и регионална и локална самоуправа. Засновано на истраживању које је спроведено у градовима Словачке Републике (СР), у којима тренутно живи 55\% становника Словачке, овај рад представља тренутно стање и ниво значаја задовољства локалног становништва у односима са локалним властима, као алат "CiRM". Рад такође указује и на извесне недостатке у литератури која се бави сличним истраживањем, посебно на нивоу СР.
\end{abstract}

Кључне речи: “CiRM”, комуникација, грађани, општине, региони

\section{References}

Alcaraz-Quiles, F.J., Navarro-Galera, A., \& Ortiz-Rodríguez, D. (2014). Factors influencing the transparency of sustainability information in regional governments: an empirical study. Journal of Cleaner Production, 82, 179-191.

Anttiroiko, A.-V., \& Mälkiä, M. (2007). Encyclopedia of Digital Government. USA: Idea Group Reference.

Burt, A., Oldfield, S., \& Ruston, S. (2005). From Customer Relationship Management to Citizen Interaction Platform. Online document. Cit. [2014-08-18] Available on the Internet: http://www.carmenproject.org/uploads/CAR MEN-white-paper-v1.0.pdf

Caywood, C.L. (2003). Public relations driven communication of the organization with the public. Brno, Computer Press. (in Czech)

Coleman, C. (2004). Citizen Relationship Management. U.S. General Services Administration, (14) 6.

Foret, M. (2011). Marketing communication. Brno, Computer press: $379-$ 425. (in Czech)

Hudáková, M. (2006). New trends in Public Relations. Brno, Masarykova univerzita: 67-71. (in Slovak)

Kannabiran, G., Xavier, M.J., \& Anantharaaj, A. (2004). Enabling egovernance through citizen relationship management-concept, model and applications. Journal of Services Research, 4 (2), 223-240.

Kubica, P. (2008). Effective 
communication of municipalities: 8-12. (in 10: 188-192.

Slovak)

Mura, L. (2012). Performance of Human

Resource Management in an Internationally

Operating Company. Serbian Journal of

Management, 7 (1), 115-129.

Malik, N. (2010). A Study On Motivational Factors of The Faculty Members At University Of Balochistan. Serbian Journal of Management, 5 (1), 143149.

Novotný, J. (2010). The personality of the innovative manager. In EDAMBA 2010: 371-374. (in Slovak)

Novotný, J. (2013). Some aspekt of the CRM implementation in business practice. $\mathrm{E}$ - studies, 4 (6), 7. (in Slovak)

Rebeca. R. (2014). Žilina self-governing region launches the project of transparency under the topic „open region“ (in Slovak). Online document. [Cit. 2014-07-28] Available on the Internet: http://rebeca.sk/?p=3448

Rimarčík, M. (2007). Statistics for practice. Košice, Marián Rimarčík: 200. (in Slovak)

Shan, L.Ch., Panagiotopoulos, P., Regan, Á., De Brún, A., Barnett, J., Wall, P., \& McConnon, Á. (2015). Interactive Communication with the public: qualitative exploration of the use of social media by food and health organizations. Journal of Nutrition Education and Behavior, 47 (1), 104-108.

Schellong, A. \& Langenberg, T. (2007). Managing Citizen Relationship in Disasters: Huricane Wilma, 311 and Miami-Dade Country. 40th International Conference on System Sciences. Hawai: IEEE.

Vidová, J. Partila, J., Mihoková, L. (2007). Increasing the effectiveness of marketing communication in the organization (in Slovak). Transfer inovácií.
Act of the National Council of the Slovak Republic No.369/1990 Coll. onmunicipal administration, as amended.

Act No. 211/2000 Coll. on free Access to information, In: Act No. 211/2000 Coll. on free accessto information and amending and supplementing certain laws (Freedom of Information Act).

Web references:

Town of Martin http://www.martin.sk/transparentnemesto/d-5999/p1=1048

Town of Šal'a http://www.sala.sk/cms.article/default/569/ot vorene-mesto 